\title{
PENCEGAHAN RESIKO KECELAKAAN JATUH DARI KETINGGIAN PADA PEKERJAAN INDUSTRI KONSTRUKSI DI INDONESIA
}

\author{
Nurhijrah $^{1)}$ \\ ${ }^{1)}$ Dosen Fakultas Teknik Universitas Andi Djemma Palopo \\ ${ }^{1)}$ nurhijrahbakri@yahoo.com
}

\begin{abstract}
Abstrak
Industri konstruksi memiliki resiko kecelakaan kerja yang cukup tinggi. Salah satu kegiatan yang mempunyai potensi kecelakaan kerja ialah bahaya jatuh bagi pekerja di ketinggian. Bekerja pada ketinggian adalah kegiatan kerja pada tempat atau titik kerja yang bila seorang bekerja ditempat tersebut, mempunyai potensi bahaya jatuh karena adanya perbedaan elevasi. Tulisan ini disusun bertujuan untuk mengidentifikasi kasus-kasus kecelakaan kerja akibat jatuh dari ketinggian yang pernah terjadi di indonesia dalam dua tahun terakhir (2013-2015) dan mendeskripsikan beberapa solusi desain yang dapat mengurangi resiko kecelakaan tersebut. Dari hasil pengumpulan data dari beberapa media online, diketahui bahwa masih banyaknya kasus kecelakaan kerja yang terjadi akibat jatuh dari ketinggian di Indonesia. Kecelakaan tersebut terjadi karena kurangnya penerapan sistem manajemen K3 pada proyek yang sedang dilakukan. Beberapa hasil penelitian menyatakan bahwa faktor desain signifikan memperngaruhi terjadinya kecelakaan kerja. Oleh karena itu, diperlukan kesadaran dari arsitek dan pemilik bangunan agar mempertimbangkan keselamatan pekerja dalam proses desain bangunan. Pengaplikasian safety design yang permanen merupakan solusi yang efektif dan efisien dalam mengurangi resiko jatuh dari ketinggian, karena dapat melindungi pekerja mulai dari proses konstruksi sampai pada proses demolish bangunan, serta menghemat biaya pekerjaan proyek. Adapun beberapa alternatif desain permanen yang dapat diaplikasikan pada bangunan, seperti: pemasangan guardrail, paraphet, penutup lubang skylight, angker atap dan jalur permanen ke atap bangunan.
\end{abstract}

Kata Kunci: Bahaya Jatuh, K3 Pekerjaan Konstruksi, dan Safety Design.

\section{PENDAHULUAN}

Industri jasa konstruksi merupakan salah satu sektor yang memiliki resiko kecelakaan kerja yang cukup tinggi. Proses pembangunan proyek kontruksi gedung pada umumnya merupakan kegiatan yang banyak mengandung unsur bahaya, terlihat sangat kompleks serta sulit dilaksanakan. Kementerian Ketenagakerjaan mencatat jumlah kecelakaan kerja yang dialami pekerja konstruksi di Indonesia per tahun 2015 relatif tinggi yaitu 31,9 persen dari total kecelakaan.

Kecelakaan pada satu pekerjaan konstruksi kebanyakan disebabkan oleh tenaga kerja yang tidak berpengalaman terhadap apa yang dia kerjakan, peralatan yang sudah tidak layak untuk dipakai, kondisi lingkungan kerja yang tidak aman, menggunakan peralatan tidak sesuai dengan peruntukannya, perilaku karyawan kurang peduli terhadap kemanan, serta management perusahaan yang belum peduli sepenuhnya terhadap keselamatan serta metode kerja yang aman. Terlebih lagi, adanya anggapan bahwa program K3 hanya akan menjadi tambahan beban biaya perusahaan. Padahal jika diperhitungkan akan lebih besar dana yang dikeluarkan oleh perusahaan untuk kompensasi/santunan korban kecelakaan kerja sebagai akibat diabaikannya Sistem Manajemen K3.

Kecelakaan yang terjadi di konstruksi terkadang mengakibatkan cacat seumur hidup, bahkan sampai pada resiko kematian (Fung, dkk. 2009). Selain itu berdampak pula pada kerugian non-materil, seperti tertundanya proyek kerja, penambahan biaya dan rusaknya reputasi dari perusahaan yang bersangkutan (Gan golells dkk. 2010). Undang Undang No. 1 tahun 1970 menyatakan bahwa salah satu kegiatan kerja yang perlu mendapat perhatian dari sisi keselamatan kerja adalah kegiatan kerja yang 
dilakukan pada ketinggian, yaitu kegiatan yang mempunyai potensi bahaya jatuh bagi pekerja yang melakukannya kegiatan itu dapat dilakukan pada ketinggian Banyak masalah yang timbul ketika pekerja bekerja di ketinggian misalnya pekerja tidak menggunakan alat pelindung diri (Full Body Harness), bekerja tidak mematuhi prosedur yang ada, dan kurangnya sistem pangamanan yang tersedia di tempat kerja.

Pada tulisan ini, dideskripsikan beberapa kasus kecelakaan jatuh dari ketinggian yang terjadi di Indonesia dan mengidentifikasi penyebab terjadinya kecelakaan tersebut. Lebih lanjut, dideskripsikan beberapa upaya pencegahan kecelakaan dalam hal bekerja di ketinggian, sehingga dapat menjaga keselamatan pekerja konstruksi dari risiko terjatuh yang dapat mengakibatkan kecelakaan fatal.

a) Bekerja di Ketinggian

Bekerja di ketinggian adalah bekerja pada suatu tempat tinggi yang dapat beresiko membuat pekerja mengalami cidera jika jatuh dari tempat tersebut (HSE UK, 2007). Dari seluruh pekerjaan di ketinggian yang ada, pekerjaan jasa konstruksi yang dilakukan di ketinggian memiliki resiko paling tinggi. Sedangkan menurut Working at height Procedure PT. BBS, bekerja di ketinggian merupakan suatu pekerjaan yang dilakukan pada ketinggian lebih dari 2 merer diatas tanah diluar proteksi pagar.

Menurut Management System (2010) bekerja pada ketinggian dapat dikategorikan sebagai berikut:

1) Bekerja di ketinggian 4 feet (1.24 meter) atau lebih dari atas lantai atau tanah. Contoh: Pekerjaan sipil (civil work), pekerjaan elektrikal atau pemasangan kabel, pemasangan panel-panel, pekerjaan bangunan (building atau structural work) seperti pemasangan atap, pembangunan jembatan. Pekerjaan tersebut dapat dilaksanakan baik oleh karyawan sendiri ataupun oleh kontraktor.

2) Bekerja pada ketinggian 6 feet (1.8) atau lebih pada pinggiran atau sisi yang terbuka.

3) Contoh: Bekerja pada atap datar (flat roof), puncak tangki timbun.

4) Bekerja di ketinggian 10 feet (3.1 meter) atau lebih pada pinggiran atau sisi yang terbuka dengan menggunakan peralatan mekanis

b) Resiko Kecelakaan Kerja di Ketinggian

Menurut UU RI Nomor 3 Th. 1992 tentang Jaminan Sosial Tenaga Kerja, kecelakaan kerja adalah kecelakaan yang terjadi berhubungan dengan hubungan kerja, termasuk penyakit yang timbul akibat kerja, demikian pula kecelakaan yang terjadi dalam perjalanan berangkat dari rumah menuju ke tempat kerja dan pulang ke rumah melalui jalan yang biasa atau wajar dilalui.

Kecelakaan kerja yang paling beresiko terjadi di konstruksi ialah terjatuh dari ketinggian. Beberapa bahaya di tempat tinggi yang dapat memicu terjadinya kecelakaan antara lain ialah: terjatuh, terpeleset, tersandung, dan kejatuhan (New British Standar, 2005). Pekerja beresiko jatuh selama proses konstruksi, perawatan, renovasi dan peruntuhan (pemusnahan) bangunan. Beberapa bagian dari bangunan yang berbahaya ialah tepi lantai dan atap, platform tinggi, lubang skylight, ruang mesin dan tangga. Bahaya jatuh dapat terjadi dari struktur yang dipasang sementara pada saat konstruksi dan perawatan, seperti: tiang perancah dan tangga atau dari struktur permanen seperti atap. 
c) Hirarki Kontrol Bekerja di Ketinggian

Desainer seharusnya mempertimbangkan kebutuhan pencegahan dari resiko jatuh untuk melindungi pekerja konstruksi, penghuni dari gedung dan pekerja perbaikan dari bahaya jatuh. Sebuah desain yang aman dapat membantu mengevaluasi pekerjaan yang dapat membahayakan pekerja. Desainer dan ahli K3 dapat menggunakan hirarki kontrol untuk mengelola dan menentukan peralatan/perlengkapan yang dipakai dalam bekerja di ketinggian. Hal ini berguna untuk mendapatkan langkah pencegahan yang relevan ketika bekerja di ketinggian (Gambatese et al.2005).

1) Sebisa mungkin pekerjaan dilakukan tanpa harus terpapar bahaya ketinggian (eliminasi), misalnya dengan pengaturan desain awal bangunan, tahap perencanaan konstruksi, dan pemilihan kontraktor.

2) Jika eliminasi tidak mungkin dilakukan, maka hal yang perlu dilakukan adalah mengisolasi pekerja dari bahaya jatuh. Hal ini dapat dilakukan dengan penggunaan platform, pagar pembatas, perancah, pengaman untuk membatasi akses/jalur.

Jika eliminasi dan isolasi tidak memungkinkan dilakukan, maka langkah yang dapat diambil adalah meminimalkan tingkat keparahan. Seperti penentuan posisi pekerjaan, penggunaan akses tali, penggunaan sistem penahan jatuh.

\section{HASIL DAN PEMBAHASAN}

Tingkat kecelakaan kerja di Indonesia tergolong tinggi dibanding sejumlah negara di Asia dan Eropa. Sampai pada tahun 2010, rata-rata pekerja yang meninggal dunia akibat kecelakaan kerja di Indonesia ialah sebanyak tujuh pekerja setiap harinya (Zalaya, 2012). Hampir 32\% kasus kecelakaan kerja di Indonesia terjadi di sektor konstruksi yang meliputi semua jenis pekerjaan proyek gedung, jalan, jembatan, terowongan dan lain-lain. Dari beberapa kasus kecelakaan kerja di konstruksi tersebut, kecelakaan akibat terjatuh dari tempat tinggi merupakan faktor dominan yang menjadi penyebabnya.

Seperti yang terlihat pada gambar 1, bahwa beberapa faktor dapat menjadi penyebab terjadinya kecelakaan kerja dikonstruksi, seperti: faktor manusia, faktor peralatan, dan faktor lingkungan. Ketiga faktor ini saling berkaitan dan tidak dapat dipisahkan. Kelalaian pada keseluruhan elemen ini dapat dianggap sebagai suatu kegagalan manajemen yang dapat mengakibatkan unsafe work methods, equipments and procedures sehingga dapat menyebabkan kecelakaan (Abduh, 2010).

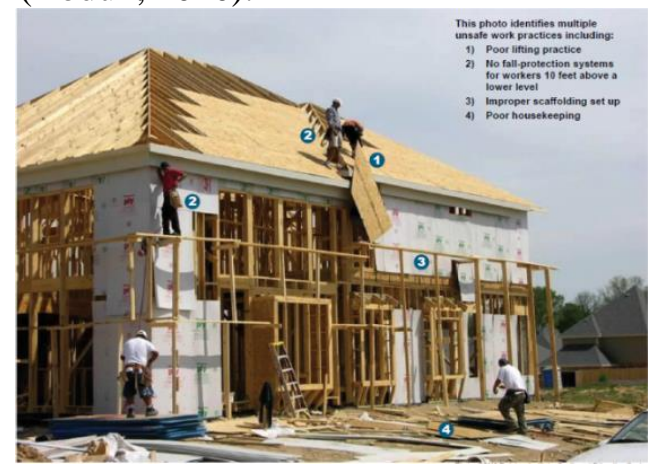

Gambar 1. Contoh pekerjaan konstruksi yang tidak aman (Sumber: OSHA, 2001)

Pada tabel 1 , terdaftar beberapa kasus kecelakaan kerja konstruksi yang pernah terjadi di Indonesia akibat terjatuh dari ketinggian. Kasus-kasus kecelakaan tersebut yang dikumpulkan dari dua tahun terakhir dari beberapa media online, diduga hanyalah 
merupakan sebagian dari kasus kecelakaan kerja yang terjadi. Hal ini karena biasanya pada proyek-proyek kecil, kasus kecelakaan kerja tidak diliput oleh media.

Tabel 1. Kasus kecelakaan kerja konstruksi akibat jatuh dari ketinggian di Indonesia

\begin{tabular}{|c|c|c|c|c|c|c|}
\hline No & Tahun & Jenis Pekerjaan & Elevasi & Penyebab & Safety & Akibat \\
\hline 1 & 2015 & $\begin{array}{l}\text { Pembangunan gedung } \\
\text { elektronik LG }\end{array}$ & $21 \mathrm{~m}$ & $\begin{array}{l}\text { Terpeleset saat melepas jaring. } \\
\text { Kayu penyanggah tempat korban } \\
\text { berpijak dalam kondisi licin. }\end{array}$ & - & $\begin{array}{l}\text { Meninggal } \\
\text { Dunia }\end{array}$ \\
\hline 2 & 2015 & $\begin{array}{l}\text { Proyek Apartemen St Moriz, } \\
\text { Kembangan, Jakarta Barat }\end{array}$ & $63 \mathrm{~m}$ & $\begin{array}{l}\text { Pembatas lift yang berlubang } \\
\text { tidak dipasang jaring, }\end{array}$ & - & $\begin{array}{l}\text { Meninggal } \\
\text { Dunia }\end{array}$ \\
\hline 3 & 2015 & $\begin{array}{l}\text { Pemasangan Rapter tangki } \\
\text { CPO }\end{array}$ & $27 \mathrm{~m}$ & Jatuh ke bawah dasar tangki & Ada & $\begin{array}{l}\text { Meninggal } \\
\text { dunia }\end{array}$ \\
\hline 4 & 2015 & $\begin{array}{llr}\begin{array}{l}\text { Pembangunan } \\
\text { Badan/Dinas } \\
\text { Minsel }\end{array} & \text { di } & \text { Kantor } \\
\text { Pemkab }\end{array}$ & $30 \mathrm{~m}$ & $\begin{array}{l}\text { memasang atap almenium pada } \\
\text { proyek } \\
\text { tidak menggunakan safety }\end{array}$ & Tidak & Luka-Luka \\
\hline 5 & 2015 & $\begin{array}{l}\text { Proyek gedung Jalan Kebon } \\
\text { Sirih Menteng }\end{array}$ & $7 \mathrm{~m}$ & $\begin{array}{l}\text { Memplester dinding di lantai IV, } \\
\text { tiba-tiba kakinya terpleset lalu } \\
\text { terjatuh. }\end{array}$ & & Luka-Luka \\
\hline 6 & 2015 & $\begin{array}{l}\text { Bangunan yang berada di } \\
\text { Jalan Pluit Timur I No 1, } \\
\text { Kelurahan Pluit, Kecamatan } \\
\text { Penjaringan, Jakarta Utara }\end{array}$ & $7 \mathrm{~m}$ & $\begin{array}{l}\text { Membongkar pasang atap dan } \\
\text { kemudian terpeleset }\end{array}$ & Tidak & Luka-Luka \\
\hline 7 & 2015 & $\begin{array}{l}\text { Gedung Telkom Landmark } \\
\text { Tower }\end{array}$ & $10 \mathrm{~m}$ & $\begin{array}{l}\text { Emmasang pipa AC terpeleset } \\
\text { dan terjatuh sampai }\end{array}$ & - & $\begin{array}{l}\text { Meninggal } \\
\text { dunia }\end{array}$ \\
\hline 8 & 2014 & $\begin{array}{l}\text { Renovasi bangunan yang } \\
\text { terbakar dan ingin }\end{array}$ & $26 \mathrm{~m}$ & $\begin{array}{l}\text { Melepas tali jaring dan kemudian } \\
\text { terpeleset }\end{array}$ & - & $\begin{array}{l}\text { Meninggal } \\
\text { dunia }\end{array}$ \\
\hline 9 & 2013 & $\begin{array}{l}\text { Proyek pembangunan } \\
\text { apartemen North Land Ancol, } \\
\text { Pademangan Barat, Jakarta } \\
\text { Utara. }\end{array}$ & $75 \mathrm{~m}$ & $\begin{array}{l}\text { memindahkan material dari atas } \\
\text { truk ke lantai } 25 \text { dengan crane. } \\
\text { Saat itu ketiganya terperosok } \\
\text { kemudian terjatuh }\end{array}$ & - & $\begin{array}{l}\text { Meninggal } \\
\text { dunia }\end{array}$ \\
\hline 10 & 2014 & $\begin{array}{l}\text { pembangunan superblok } \\
\text { prestisius Podomoro City } \\
\text { Medan }\end{array}$ & $15 \mathrm{~m}$ & $\begin{array}{l}\text { Memasang jaring pembatas } \\
\text { rangka baja }\end{array}$ & - & Luka-Luka \\
\hline 11 & 2014 & $\begin{array}{l}\text { Perbaikan lampu Gedung } \\
\text { Olahraga (GOR) Tangerang }\end{array}$ & $12 \mathrm{~m}$ & $\begin{array}{l}\text { Tangga yang digunakan ambruk } \\
\text { hingga membuat kedua korban } \\
\text { terjatuh dari ketinggian }\end{array}$ & Tidak & $\begin{array}{l}\text { Meninggal } \\
\text { dunia }\end{array}$ \\
\hline 12 & 2014 & Proyek Tower Alila & $69 \mathrm{~m}$ & $\begin{array}{l}\text { Mempergunakan lift tersebut } \\
\text { menuju, tiba-tiba saja kabel lift } \\
\text { personnel hoist tersebut putus. }\end{array}$ & - & $\begin{array}{l}\text { Meninggal } \\
\text { dunia }\end{array}$ \\
\hline 13 & 2014 & Proyek Rasuna Tower & $52 \mathrm{~m}$ & $\begin{array}{l}\text { Terjatuh karena menginjak } \\
\text { railing besi yang patah }\end{array}$ & - & $\begin{array}{l}\text { Meninggal } \\
\text { dunia }\end{array}$ \\
\hline 14 & 2014 & $\begin{array}{l}\text { Pembersih kaca gedung Hotel } \\
\text { Ritz Carlton Mega }\end{array}$ & $75 \mathrm{~m}$ & Terjatuh dari gondola & - & $\begin{array}{l}\text { Meninggal } \\
\text { dunia }\end{array}$ \\
\hline 15 & 2014 & $\begin{array}{l}\text { Proyek pembangunan } \\
\text { apartemen Green Pramuka }\end{array}$ & $80 \mathrm{~m}$ & $\begin{array}{l}\text { Melempar material semen dan } \\
\text { kaki korban tersangkut sehingga } \\
\text { kehilangan keseimbangan. Dan } \\
\text { terjatuh }\end{array}$ & Tidak & $\begin{array}{l}\text { Meninggal } \\
\text { dunia }\end{array}$ \\
\hline 16 & 2013 & $\begin{array}{l}\text { Proyek di Lotte Mart, Ciputat, } \\
\text { Kota Tangerang Selatan }\end{array}$ & $10 \mathrm{~m}$ & $\begin{array}{l}\text { Terjatuh saat memperbaiki atap } \\
\text { parkiran }\end{array}$ & - & $\begin{array}{l}\text { Meninggal } \\
\text { dunia }\end{array}$ \\
\hline 17 & 2013 & $\begin{array}{l}\text { Proyek Pembangunan Hotel } \\
\text { The Mansion, Kawasan Mega } \\
\text { Kuningan, Kuningan Timur }\end{array}$ & $27 \mathrm{~m}$ & Terjatuh karena kelelahan & - & $\begin{array}{l}\text { Meninggal } \\
\text { dunia }\end{array}$ \\
\hline 18 & 2013 & Pekerjaan Masjid Agung & & $\begin{array}{l}\text { Menaikkan material bangunan } \\
\text { dengan katrol di konstruksi } \\
\text { menara }\end{array}$ & - & Luka-Luka \\
\hline
\end{tabular}

Ket : - Tidak ada keterngan

Dari beberapa kasus kecelakaan kerja yang terjadi di indonesia (lihat Tabel 1), penyebab dari kecelakaan tersebut beragam, seperti: kelalaian dari pekerja yang tidak menggunakan perlatan keamanan, kurangnya pengawasan dari pengawas konstruksi serta tidak tersedianya pengaman di bangunan. Hal ini menggambarkan bahwa masih kurangnya penerapan sistem manajemen K3 di industri konstruksi di Indonesia (lihat gambar 2). 


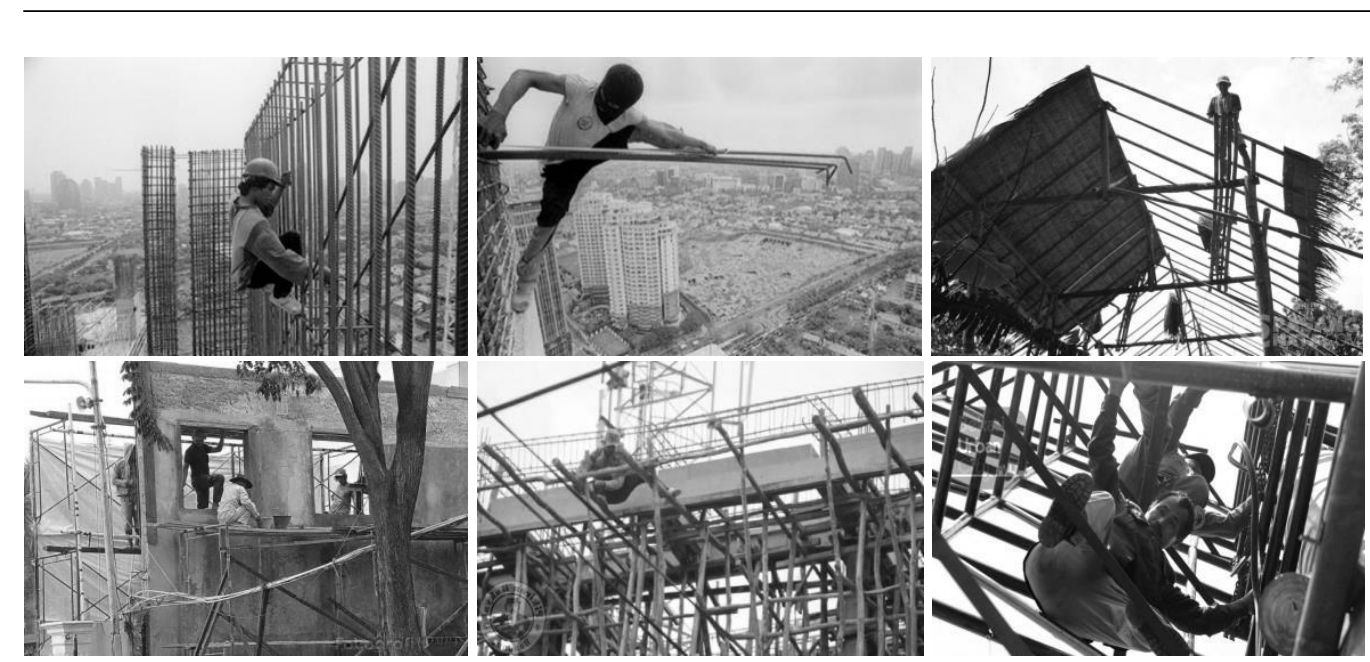

Gambar 2. Budaya konstruksi di Indonesia

Adapun hal lainnya yang menjadi permasalahan pencegahan kecelakaan konstruksi di Indonesia, yaitu pihak manajemen kontraktor biasanya berfokus pada usaha pencegahan kecelakaan yang disebabkan oleh faktor manusia, seperti: melakukan pelatihan tenaga kerja, penggunaan alat proteksi diri, disiplin kerja dan lain-lain. Usaha tersebut bukan tidak membuahkan hasil, tetapi merupakan usaha yang sulit dilaksanakan dengan efektif mengingat faktor manusia atau personil ini akan sangat terkait dengan latar belakang pendidikan, kebiasaan, budaya, serta motivasi pekerja. Dalam kondisi budaya kerja di Indonesia sendiri, membenahi faktor manusia membutuhkan waktu yang tidak sebentar dan usaha yang sangat besar.

Jika merujuk pada hirarki kontrol untuk pencegahan terjadinya kecelakaan kerja di konstruksi, hal yang lebih mudah dilakukan oleh pihak manajemen konstruksi ialah mengeliminasi kemungkinan pekerja untuk melakukan pekerjaan di ketinggian atau membuat desain konstruksi yang aman. Pada proses inilah sebenarnya diperlukan kesadaran dari arsitek, desainer maupun pemilik proyek untuk menjamin keselamatan perkerjanya.

Berdasarkan keputusan bersama Menteri tenaga kerja dan Menteri Pekerjaan Umum tentang Keselamatan dan kesehatan Kerja pada tempat Konstruksi, pengusaha memiliki tanggung jawab atas keselamatan pekerjanya. Sedangkan, tanggung jawab arsitek atau desainer atas keselamatan pekerja konstruksi tidak dijelaskan secara jelas dalam aturan tersebut. Oleh karena itu, arsitek dan desainer tidak selalu mempertimbangkan bahaya yang dapat mengancam keselamatan pekerja pada saat proses desain bangunan. Selain itu, tuntutan waktu dari pemilik bangunan dan adanya pembatasan dana, biasanya menjadi faktor yang menyebabkan arsitek atau desainer untuk mengabaikan keselamatan dan kesehatan bangunan (Gambatese et al, 2005; Toole and Gambatese, 2008)

Arsitek maupun desainer sebenarnya memegang peranan yang penting dalam pencegahan resiko jatuh dari ketinggian pada kegiatan konstruksi. Hasil penemuan dari Australian Study 2000-2002 menyatakan bahwa desain bangunan signifikan menyebabkan kecelakaan kerja. Oleh karena itu, seharusnya dengan perencanaan desain konstruksi bangunan yang baik, pekerjaan di ketinggian dapat dihilangkan atau setidaknya menjadi lebih aman.

Pada budaya konstruksi di Indonesia sendiri, seringkali pengamanan pekerjaan diketinggian hanya dipasang secara sementara dan menggunakan material yang tidak cukup kokoh. Padahal disadari bahwa kecelakaan kerja akibat jatuh dari ketinggian tidak hanya terjadi pada saat proses konstruksi, tetapi juga dapat terjadi pada tahap pemeliharaan dan penghancuran bangunan. Kurangnya kesadaran dari pihak-pihak yang terlibat dalam proyek bangunan gedung di Indonesia ini, disebabkan oleh masalah biaya yang diperhitungkan oleh pihak pemilik dan kontraktor proyek. 
Apabila ditinjau dari aspek penghematan biaya, pemasangan fitur-fitur pengaman pada desain konstruksi bangunan sangatlah lebih hemat dibanding dengan pemasangan pengamanan secara temporal (Gambatese dkk. 1997). Ditambahkan lagi hasil penelitian dari Rajendran dan Gambatese (2013), bahwa pemasangan angker sebagai pengamanan pekerjaan atap sangatlah murah (lihat gambar 3). Keuntungan lainnya juga ialah dengan pemasangan pengamanan secara permanen, pekerja yang bekerja diketinggian tetap terjaga keselamatannya pada saat tahap pemeliharaan dan penghancuran bangunan.

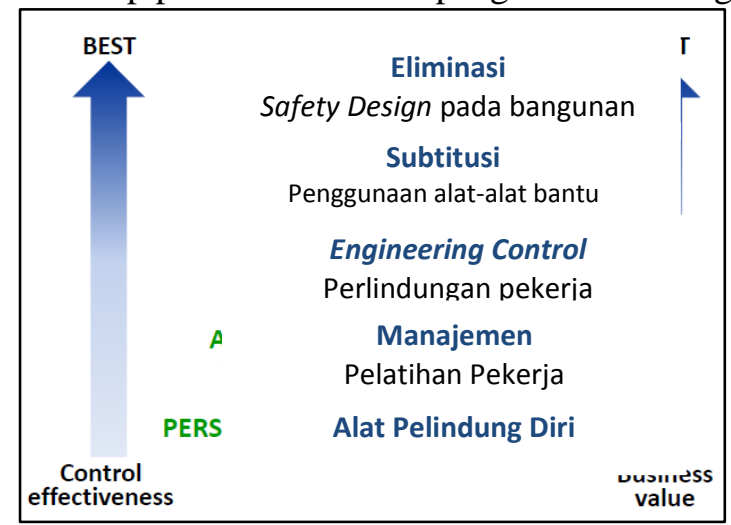

Gambar 3. Hirarki Kontrol Keselamatan pekerja

Oleh karena itu, pencegahan bahaya jatuh yang paling efektif dan efisien adalah dengan mengaplikasikan safety design secara permanen pada bangunan. Adapun beberapa alternatif safety design tersebut ialah sebagai berikut:

Tabel 2. Penerapan safety design permanen pada bangunan

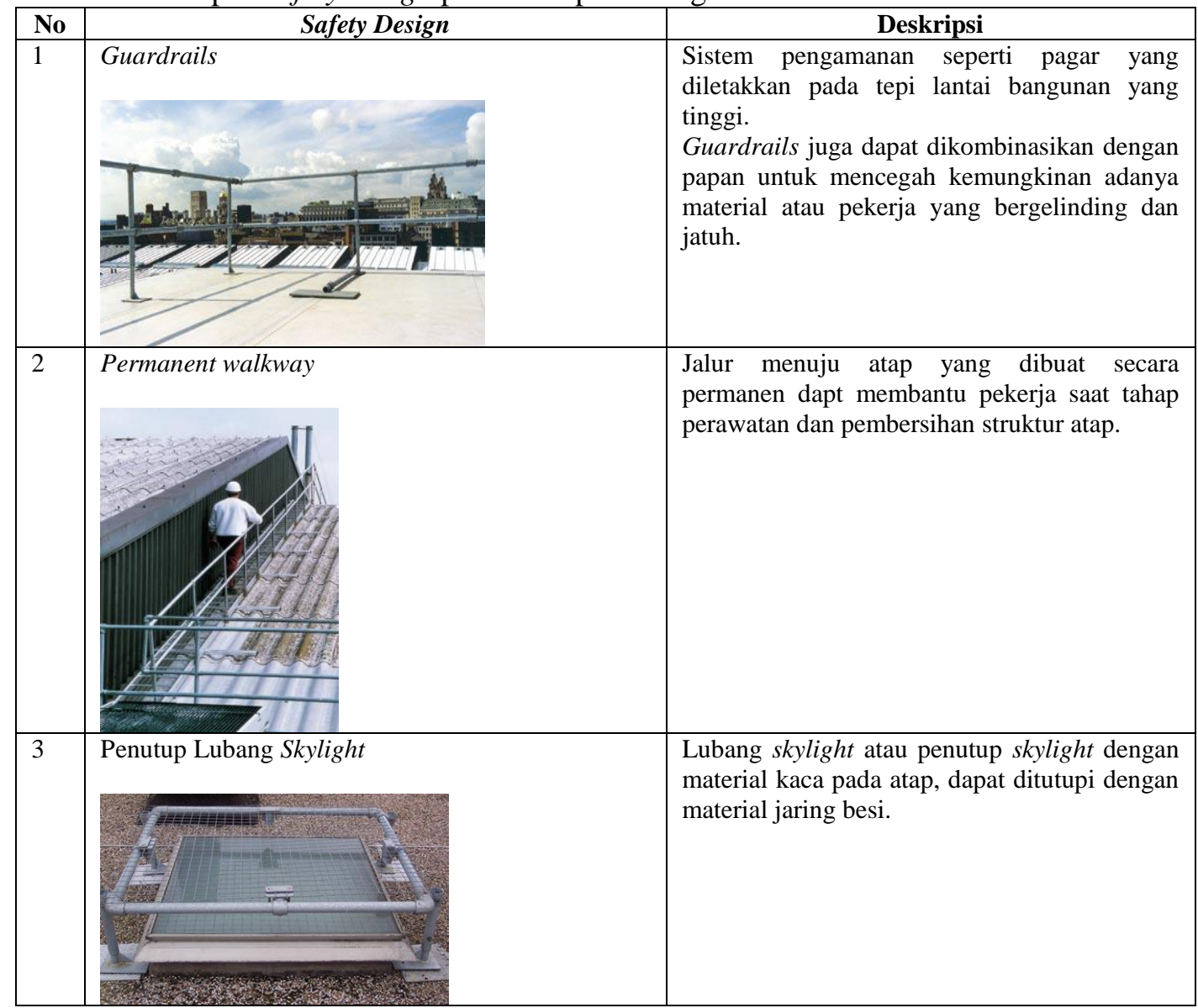




\begin{tabular}{|c|c|c|}
\hline 4 & Panel pada dinding & $\begin{array}{l}\text { Alternatif lainnya yaitu panel skylight tidak } \\
\text { diaplikasikan pada atap, tetapi pada struktur } \\
\text { dinding bangunan }\end{array}$ \\
\hline 5 & Paraphet & $\begin{array}{l}\text { Paraphet merupakan struktur dinding menerus } \\
\text { pada atap yang juga dapt melindungi resiko } \\
\text { ajtuh dari ketinggian, dengan ketinggian } \\
\text { minimal 39". }\end{array}$ \\
\hline 6 & Anchor point & $\begin{array}{l}\text { Pemasangan titik-titik angker sebagai bagian } \\
\text { dari struktur atap dapat membantu pekerja saat } \\
\text { pekerjaan konstruksi dan perawatan bangunan. }\end{array}$ \\
\hline
\end{tabular}

Pada tabel 2, telah dijelaskan beberapa alternatif safety design yang dapat diaplikasikan pada bangunan. Demi keselamatan para pekerja dan penghuni bangunan, sudah seharusnya arsitek memprioritaskan konsep tersebut dalam proses perencanaan bangunan. Dalam NIOSH 2013, dijelaskan beberapa tahapan yang dapat dilakukan oleh seorang arsitek dan pemilik bangunan untuk melakukan pencegahan resiko jatuh dari ketinggian pada bangunan ialah sebagai berikut:

1) Pada saat proses retrofit, renovasi atau konstruksi baru, dilakukan review terhadap safety design untuk mengidentifikasi dan mempertimbangkan pekerjaan yang memiliki resiko jatuh.

2) Konsultasi dengan profesional enjiner yang bersertifikat pada saat memasang fitur pengaman secara permanen pada bangunan

3) Pada tahap memulai konstruksi yang baru, arsitek dan enjiner seharusnya mempersiapkan gambar detail yang mengindikasikan bahaya jatuh dan selanjutnya menentukan sistem perlindungan yang tapet.

4) Pada saat pemasangan sistem pengamanan, pastikan diawasi oleh seorang yang ahli dan pengaman sebaiknya diuji cobakan sebelum dinyatakan layak untuk digunakan.

Perencanaan bangunan yang mengikuti tahap-tahap berikut diatas, akan mampu mengurangi resiko jatuh dari ketinggian. Sehingga keselamatan pekerja dan penghuni bangunan tersebut akan terjamin pada saat proses proyek manapun.

\section{KESIMPULAN}

Bahaya jatuh dari ketinggian merupakan penyebab dominan kecelakaan kerja di konstruksi. Resiko jatuh dapat terjadi pada area-area seperti: tepi lantai, alat pengangkut dan lubang skylight. Peran arsitek sangatlah besar dalam mencegah resiko jatuh pekerja bangunan, karena desain bangunan signifikan berkontribusi terhadap terjadinya kecelakaan kerja akibat jatuh dari ketinggian. Dalam mengurangi 
resiko jatuh dari ketinggian pada konstruksi secara efektif dan efisien ialah dengan menghilangkan atau mengurangi pekerjaan di tempat tiggi. Hal in dapat dilakukan dengan perencanaan safety design pada bangunan secara permanen, seperti: pemasangan guardrail, paraphet, penutup lubang skylight, angker atap dan jalur permanen ke atap bangunan.

\section{DAFTAR PUSTAKA}

Abduh, Muhamad, Rizky Jatnika Sahputra, dan Bobby Boris. 2010. Pengelolaan Faktor Non-Personil Untuk Pencegahan Kecelakaan Kerja Konstruksi. Bali: Konferensi Nasional Teknik Sipil 4.

Buku Pedoman Keselamatan dan Kesehatan Kerja pada Tempat Kegiatan Konstruksi. Berdasarkan Keputusan Bersama Menterti Tenaga Kerja dan Menteri Pekerjaan Umum No. KEP 174/MEN/86, No: 104/KPTS/1986 Tentang Keselamatan dan Kesehatan kerja Pada tempat Kegiatan Konstruksi.

E. A. McKenzie, Jr., Division. 2014. Preventing Falls from Heights through the Design of Embedded Safety Features. NIOSH.

Gambatese JA, Hinze J, Haas CT. 1997. Tool to design for construction worker safety. J Arch Eng.

Healt and Safety Executive. 2007. The Work at Height Regulations 2005 (as embeded) A Brief Guide. Health and Safety Executive; United Kingdom.

Healt and Safety Executive. 2012. Health and Safety in Roof Work. Health and Safety Executive; United Kingdom.

Hecker S, Gambatese J, Weinstein M. 2005. Designing for worker safety: moving the construction safety process upstream. Professional Safety, Journal of the American Society of Safety Engineers (ASSE).

OSHA [2001]. Standard number 1926.760: fall protection. Washington, DC: U.S. Department of Labor, Occupational Safety and Health Administration.

Zalaya, Yusuf. 2012. Implementasi Prosedur Bekerja di Ketinggian di PT BBs Indonesia Tahun 2012. Tesis Universitas Indonesia 